\title{
Correlation between genotype and phenotype in primary open angle glaucoma of Brazilian families with mutations in exon 3 of the TIGR/MYOC gene
}

\author{
Correlação entre genótipo-fenótipo em famílias brasileirascom glaucoma primá riode \\ ângulo aberto determinada por mutações no exon 3 dogene TIGR/MYOC
}

\author{
Cristine Araújo Povoa ${ }^{1}$ \\ Roberto Freire Santiago Malta ${ }^{2}$ \\ Mariana de Moraes Rezende ${ }^{3}$ \\ Karla Fabiana Santana de Melo ${ }^{4}$ \\ Daniel Giannella-Neto ${ }^{5}$
}

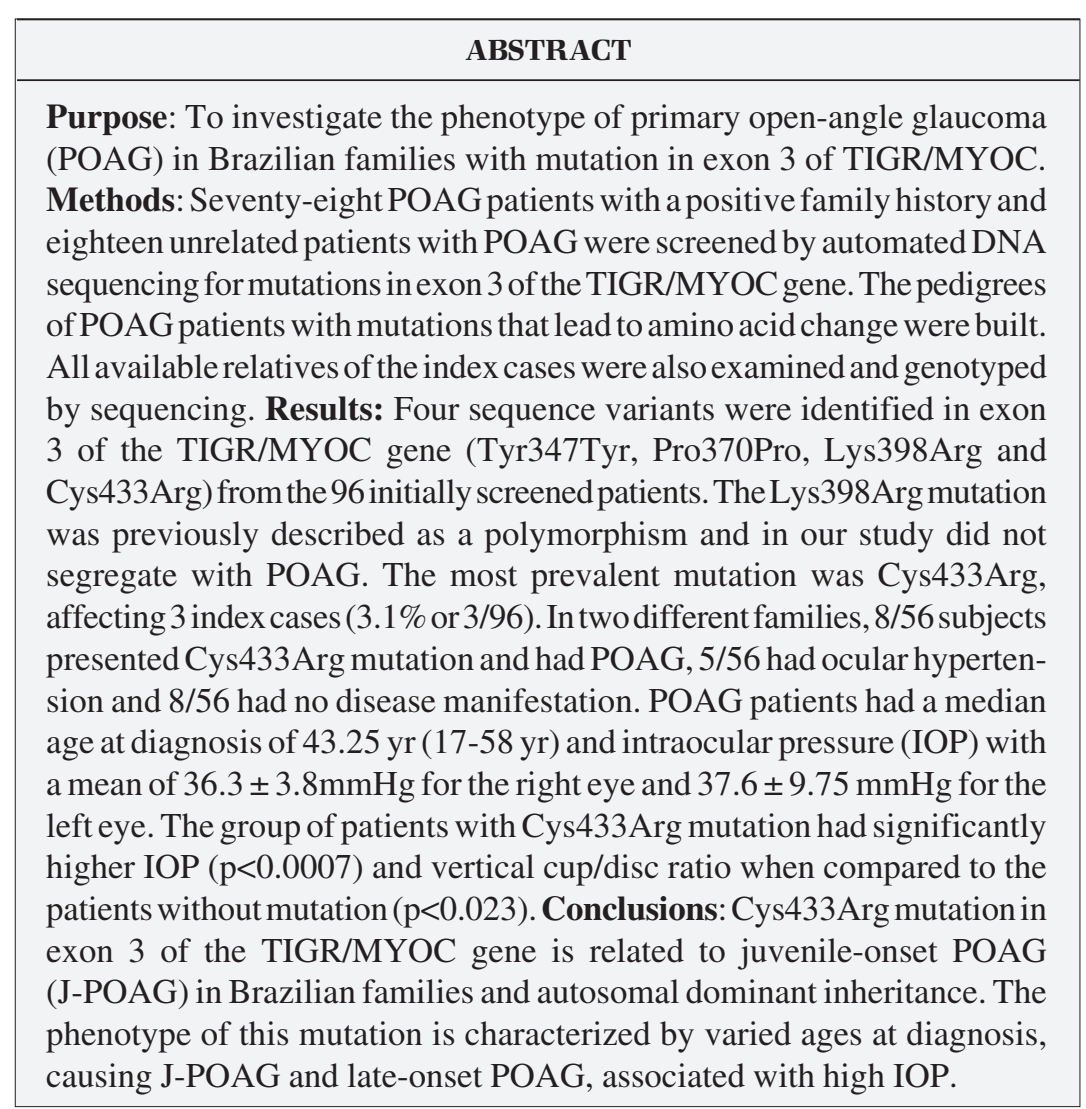

Keywords: Glaucoma, open-angle; Genes, Phenotype; Genotype; Mutation; Genetic screening; Brazil

\section{INTRODUCTION}

Glaucoma is a potentially severe ocular disease and the second leading worldwide cause of blindness, after cataract ${ }^{(1)}$. Primary open-angle glaucoma (POAG) represents more than half of all glaucoma cases in North American Caucasian populations and affects nearly $2 \%$ of subjects older than 45 years ${ }^{(1-2)}$.

The Brazilian prevalence of glaucoma is unknown. The results of screening studies suggest that the disease is frequent, the majority of the subjects is affected by POAG and the disease represents an important social problem ${ }^{(3-4)}$. 
290 Correlation between genotype and phenotype in primary open angle glaucoma of Brazilian families

with mutations in exon 3 of the TIGR/MYOC gene

The first locus responsible for POAG, named GLC1-A, was identified in $1993^{(5)}$ by genetic linkage analysis in 5 generations of a large family with juvenile glaucoma, on the long arm of chromosome 1 .

Stone et al. ${ }^{(6)}$ found mutations in exon 3 of the TIGR/ MYOC gene in $2.9 \%$ of patients with unselected glaucoma and in $4.4 \%$ of the patients with glaucoma family history. The most frequent mutation in this study was the Gln368STOP.

The subsequent studies, analyzing the prevalence of the mutation on GLC1-A, repeated the initial results and identified additional mutations, almost all located in exon 3 of the TIGR/ MYOC. Most of these mutations were missense, located in the exon 3 that encodes the olfatomedin homology domain ${ }^{(7-9)}$.

In Brazil, studies of patients with juvenile glaucoma identified a new mutation (Cys433Arg), not found in other populations, and that may be the most common TIGR/MYOC gene mutation in the Brazilian population ${ }^{(10)}$.

Considering that POAG is relatively prevalent, that our population shows specific racial characteristics resulting from strong miscegenation and that presence of mutations in the TIGR/MYOC gene influences the variation of phenotypic expression, we aimed to identify mutations in exon 3 of the TIGR/MYOC gene of POAG patients and observe the phenotypic expression of the families with the identified mutations.

\section{METHODS}

The initial cases consisted of 96 index glaucomatous patients, admitted at the Ophthalmologic Department of the "Hospital das Clínicas da Universidade de São Paulo" (HCFMUSP). The patients were selected according to the following criteria: 1) patients with POAG either juvenile-onset or adult, with or without family history of the disease; 2) ocular hypertensive patients $(\mathrm{OH})$ with positive family history of glaucoma; 3) patients with optic disc with suspicion of glaucoma (SOD), and a family history of glaucoma and 4) patients with no manifestation of disease (NDM) who had glaucomatous relatives.

The patients with glaucoma had an open angle on gonioscopy, glaucomatous optic disc features and alteration of automated visual field. The patients with open-angle gonioscopy that had intraocular pressure (IOP) of $22 \mathrm{mmHg}$ or higher, (in the absence of IOP lowering therapy), and no optic disc or visual field features suggestive of glaucoma were considered ocular hypertensives.

The patients with SOD had open angle on gonioscopy, cup/disc ratio 0.7 or greater; asymmetry of cup/disc ratio greater than 0.2 , in the absence of other alterations of the neural rim that suggest glaucoma; absence of visual field alteration and IOP levels lower than $22 \mathrm{mmHg}$.

The patients without disease manifestation (NDM) were characterized by the presence of open angle, IOP lower than $22 \mathrm{mmHg}$, optic cup/disc ratio lower than 0.7 , regular neural rim and normal visual field.

The visual field was considered altered according to the
Anderson criteria for minimal abnormality in glaucoma ${ }^{(11)}$. The visual field was not performed in children under 6 years.

Informed parental consent, patient consent, and approval by the Hospital Ethics Committee were obtained before initiating the study, according to the Declaration of Helsinki.

\section{Family studies}

Seventy-seven available relatives of 2 of the 3 index cases with mutation Cys433Arg in exon 3 of the TIGR/MYOC gene, were submitted to ophthalmologic examination, performed at the "Hospital das Clínicas da Universidade de Sao Paulo", and were screened to identify the family's mutation.

The following information was collected from the relatives: IOP, use of IOP lowering therapy or other medications, history of laser treatment and surgery for glaucoma.

The ophthalmologic examination consisted of evaluation of visual acuity with optical corrections, biomicroscopy, Goldmann applanation tonometry, gonioscopy with Sussman lens (Ocular ${ }^{\circledR}$ Instruments Bellevue, WA USA), biomicroscopy of the optic disc with 90DP lens $\left(\mathrm{Ocular}^{\circledR}\right.$ Instruments Bellevue, WA USA), standard automated visual field test (program C24-2, SITA fast strategy from Humphrey Field Analyzer (Humphrey ${ }^{\circledR}$ Instruments, CA) and stereophotography of the disc.

\section{Study of exon 3 of the TIGR/MYOC gene}

Genomic DNA of the patients and their available relatives was obtained from peripheral blood leukocytes, according to the protocol of Genomic Prep ${ }^{\mathrm{TM}}$ Blood DNA Isolation Kit (Amersham Pharmacia Biotech, Inc.). A fragment of $487 \mathrm{bp}$ corresponding to exon 3 of the TIGR/MYOC gene was amplified by PCR. The forward primer CGGGTGCTGTGGTGTACTC and reverse primer AAGAGCTTCTTCTCCAGGGG were used. Amplification conditions consisted of an initial denaturing step of $95^{\circ} \mathrm{C}$ for $3 \mathrm{~min}, 30$ cycles of $94^{\circ} \mathrm{C}$ for $1 \mathrm{~min} ; 55^{\circ} \mathrm{C}$ for 1 $\min ; 72^{\circ} \mathrm{C}$ for $1 \mathrm{~min}$; followed by a final extension step at $72^{\circ} \mathrm{C}$ for $10 \mathrm{~min}$. For sequencing $5 \mathrm{ng}$ of amplified DNA fragment were purified in a column using the supplier's instructions (GibcoBRL ${ }^{\circledR}$ Lifetechnologies, Gasthersburg/EUA) and directly sequenced with the ABI PRISM Genetic Analyser 377 automatic DNA sequencer (PE Applied Biosystems, Foster City, CA). The sequencing was made according to the supplier's protocol (ABI Prism ${ }^{\circledR}$ Big Dye Terminator Cycle Sequencing ready Reaction).

Statistical analysis was performed using the non-parametric of Mann-Whitney test. The used software was "Statistica" (version 5.5). Value of $\mathrm{p}<0.05$ was considered significant.

\section{RESULTS}

Initially, 96 individuals were screened to identify index cases: $75(78.1 \%)$ were diagnosed as POAG, $10(10.4 \%)$ were $\mathrm{OH}$, $2(2.0 \%)$ presented SOD and $9(9.3 \%)$ did not have manifestation of the disease (NDM). Eighteen patients (18.7\%) with POAG had no family history of glaucoma (Table 1 and Figure 1).

The median age of the studied patients was $66 \mathrm{yr}$, ranging from 24 to $87 \mathrm{yr}$. 
Table 1. Diagnosis and family data of the 96 index cases

\begin{tabular}{|c|c|c|c|c|c|}
\hline \multirow[b]{2}{*}{ FH } & \multicolumn{5}{|c|}{ Diagnosis } \\
\hline & POAG & $\mathrm{OH}$ & SOD & NDM & $\mathbf{N}$ \\
\hline $\mathrm{FH}+$ & 57 (59.3\%) & $10(10.4 \%)$ & $2(2.0 \%)$ & $9(9.3 \%)$ & 78 ( $81.2 \%)$ \\
\hline $\mathrm{FH}-$ & $18(18.7 \%)$ & 0 & 0 & 0 & $18(18.7 \%)$ \\
\hline $\mathrm{N}$ & 75 (78.1\%) & $10(10.4 \%)$ & $2(2.0 \%)$ & $9(9.3 \%)$ & $96(100.0 \%)$ \\
\hline
\end{tabular}

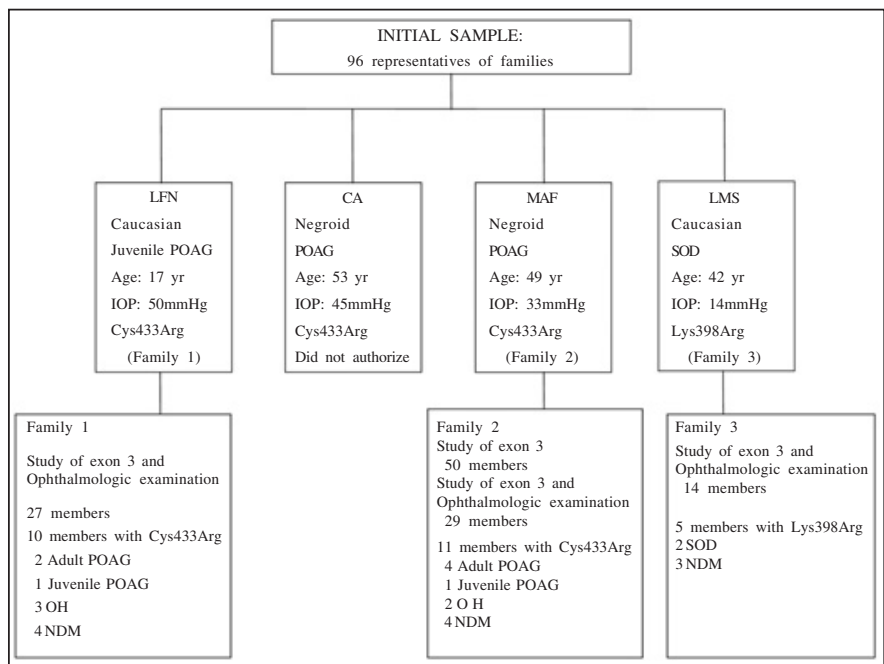

Figure 1 - Summary of the studied families, after the identification of the mutations in the index cases

Fifty-eight patients $(60.4 \%)$ were female and $38(39.5 \%)$ were male, of which 56 (58.3\%) were Caucasians, 39 (40.4\%) Negroid and $1(1 \%)$ Mongol.

\section{Mutational analysis of exon 3 of the TIGR/MYOC gene}

Four heterozygous variants (Tyr347Tyr, Pro370Pro, Lys398Arg and Cys433Arg) were detected in 6/96 subjects (6.2\%) (Table 2). Three of them (Tyr347Tyr, Pro370Pro and Lys398Arg) are not considered disease-causing mutation.

The $\mathrm{C} \rightarrow \mathrm{T}$ transition at nucleotide 1361 (Cys433Arg) was the most prevalent mutation, affecting 3 of 96 studied patients
(3.1\%). The index cases with this disease-causing mutation belonged to the same diagnosis group of POAG with a family history. Considering only this group, the frequency of the mutation Cys433Arg was 5.2\% (3/57). The Lys398Arg mutation was found in a female patient with SOD and positive family history, being present in $1 \%$ of the total sample (1/96). Pro370Pro mutation was identified in 1 patient and Tyr347Tyr mutation in another patient. Both were found in patients with POAG and a positive family history, affecting $3.5 \%$ (2/57) of the patients of this group (Table 2).

No alterations were identified in exon 3 of the TIGR/MYOC gene in the group of $\mathrm{OH}$ patients and NDM patients (Table 2).

\section{Study of the families}

The segregation study of Cys433Arg mutation and its phenotypic expression was made in 2 of the 3 families with this mutation (LFN and MAF families). The third index case did not authorize her family to participate in this study (Figure 1).

The pedigree of LFN and MAF families is shown in Figures 2 and 3 , respectively.

The LFN family index case had juvenile-onset POAG. This family had 27 members submitted to the study of exon 3 of the TIGR/MYOC gene and ophthalmologic evaluation. Ten members of this family were heterozygous for the mutation Cys433Arg (Figure 1). Two had a diagnosis of adult POAG, one of J-POAG, three were considered $\mathrm{OH}$ and four had NMD (Figure 2).

The MAF family index case had adult POAG. Fifty members of this family were submitted to analysis of exon 3 of the TIGR/ MYOC gene; but only 29 were available for ophthalmologic evaluation. Eleven members of this family were heterozygous for the Cys433Arg mutation (Figure 3): 4 had a diagnosis of adult POAG, 1 of juvenile-onset POAG; 2 were $\mathrm{OH}$, and $4 \mathrm{NDM}$.

One patient from each family was considered $\mathrm{OH}$ and did not present mutations in exon 3 of the TIGR/MYOC gene.

\section{Phenotypic characteristics of patients with POAG and Cys433Arg}

The Cys433Arg mutation was present in all available relatives of the families LFN and MAF with a diagnosis of POAG (Figures 2 and 3). Five of 8 patients $(62.5 \%)$ were female and $3 / 8(37.5 \%)$ were male. The median age at diagnosis of POAG

\begin{tabular}{|c|c|c|c|c|c|c|c|}
\hline \multirow{3}{*}{ Variations on exon 3} & \multicolumn{5}{|c|}{ Diagnosis groups } & \multirow{3}{*}{$\mathbf{N}$} & \\
\hline & \multicolumn{2}{|c|}{ POAG } & \multirow{2}{*}{$\begin{array}{c}\mathrm{OH} \\
\mathrm{FH}+\end{array}$} & \multirow{2}{*}{$\begin{array}{c}\text { SOD } \\
\mathrm{FH}+\end{array}$} & \multirow{2}{*}{$\begin{array}{c}\mathrm{NDM} \\
\mathrm{FH}+\end{array}$} & & \\
\hline & $\mathbf{F H}+$ & FH - & & & & & \\
\hline Cys433Arg & $3(3.1 \%)$ & 0 & 0 & 0 & 0 & $3(3.1 \%)$ & \multirow{4}{*}{$6(6.2 \%)$} \\
\hline Lys398Arg & 0 & 0 & 0 & 1 & 0 & $1(1.0 \%)$ & \\
\hline Pro370Pro & $1(1.0 \%)$ & 0 & 0 & 0 & 0 & $1(1.0 \%)$ & \\
\hline Tyr347Tyr & $1(1.0 \%)$ & 0 & 0 & 0 & 0 & $1(1.0 \%)$ & \\
\hline No alterations on exon & $52(54.1 \%)$ & $18(18.7 \%)$ & $10(10.4 \%)$ & $1(1.0 \%)$ & $9(9.3 \%)$ & $90(93.7 \%)$ & $90(93.7 \%)$ \\
\hline $\mathrm{N}$ & $57(59.3 \%)$ & $18(18.7 \%)$ & $10(10.4 \%)$ & $2(2.1 \%)$ & $9(9.3 \%)$ & $96(100.0 \%)$ & \\
\hline
\end{tabular}




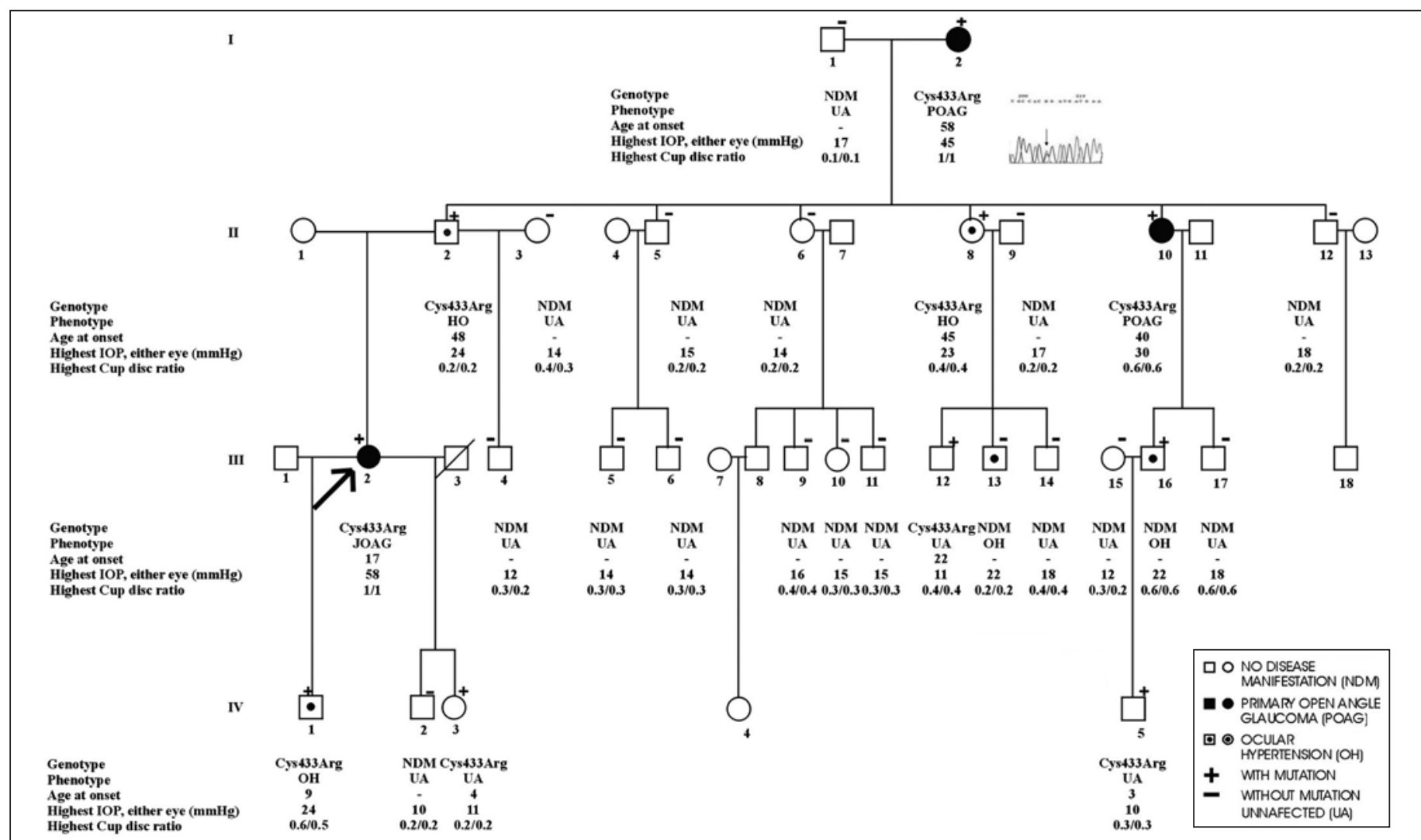

Figure 2 - Heredogram of family LFN. All the patients with POAG presented the mutation in one of the alleles. Of the ocular hypertensives (OH) only patient LFN III-13 did not present the mutation.

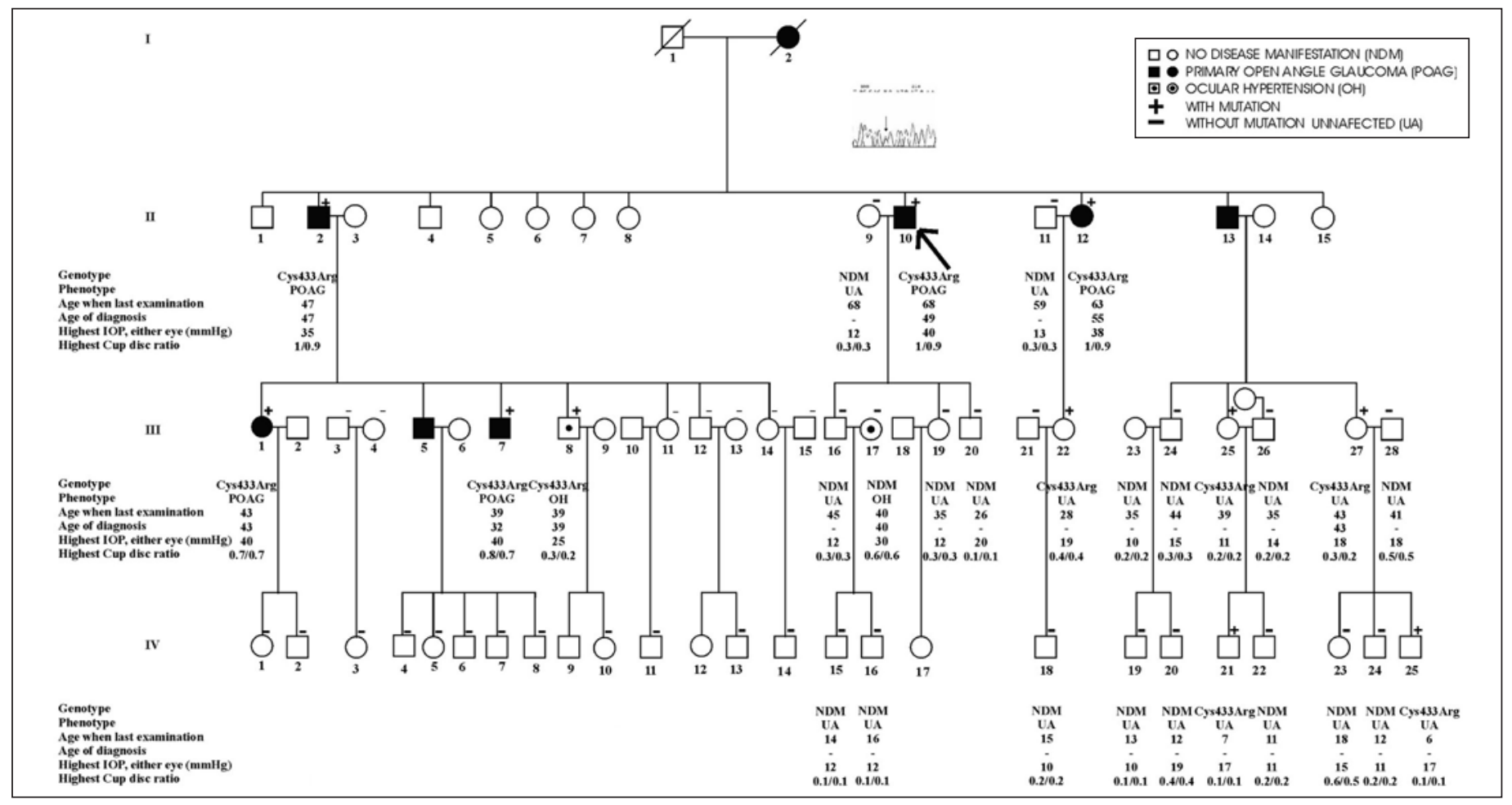

Figure 3 - Heredogram of family MAF. All the patients with POAG, and with examined genotype presented the mutation Cys433Arg. Of the OH patients, only patient MAF III-17 did not present the mutation. All the patients NDM with mutation had a mean age less than the lowest limit of the median age at diagnosis that was found in the group of patients with POAG and mutation. 
was $45 \mathrm{yr}$, ranging from 17 to $58 \mathrm{yr}$. Two patients, one from each family, presented juvenile-onset POAG (Table 3).

The age at diagnosis of juvenile-onset POAG of the LFN family's index case III- 2 was $17 \mathrm{yr}$ and that of the index case of MAF family was 49 (Table 3 ). This group of patients presented a mean of the maximal untreated IOP of $36.3 \pm 3.8 \mathrm{mmHg}$ (median of $37 \mathrm{mmHg}$, ranging from 30 to $40 \mathrm{mmHg}$ ) in the right eye and $37.6 \pm 9.75 \mathrm{mmHg}$ (median $35 \mathrm{mmHg}$, ranging from 28 to $58 \mathrm{mmHg}$ ) in the left eye (Table 3 ).

The median vertical cup/disc ratio in the right and left eyes was 0.9 and 1.0, respectively. It ranged from 0.4 to 1.0 in the right eye and 0.6 to 1.0 in the left eye.

Only 2 of 8 patients with POAG (LFN and MAF families) were not submitted to surgery to treat glaucoma and were controlled on medical therapy. The remaining six patients underwent trabeculectomy and in two of them a surgery to implant a glaucoma drainage device was also necessary.

Five of these 8 patients $(62.5 \%)$ presented visual acuity lower than 20/400 secondary to POAG in at least one of the eyes (Table 3 ).

\section{Phenotypic characteristics of $\mathrm{OH}$ patients}

Seven patients, five of LFN family and two of MAF family, were considered $\mathrm{OH}$ (Table 4). Two OH subjects, one female patient of LFN family (LFN III-13) and a male of MAF family (MAF III-17) did not present the mutation Cys433Arg in the
TIGR/MYOC gene. The patient LFN III-13 had a diagnosis of $\mathrm{OH}$ when she was $21 \mathrm{yr}$ old with IOP of $22 \mathrm{mmHg}$ in the right eye and $21 \mathrm{mmHg}$ in the left eye, vertical cup/disc ratio in the right and left eyes of 0.2 and visual acuity of 20/20 in both eyes. The patient MAF III-17 had a diagnosis of $\mathrm{OH}$ when he was $40 \mathrm{yr}$ old. He presented initial IOP of 30 in both eyes, vertical cup/disc ratio of 0.5 in the right eye and 0.6 in the left eye and visual acuity of 20/20 in both eyes. Among the five $\mathrm{OH}$ patients with mutation, one (20\%) was female.

The median age at diagnosis in the $\mathrm{OH}$ patients with mutation was $39 \mathrm{yr}$, ranging from 9 to $48 \mathrm{yr}$.

The $\mathrm{OH}$ patients presented median IOP for the right and left eye of $22 \mathrm{mmHg}$. The median vertical cup/disc ratio was 0.4 in both eyes.

All $\mathrm{OH}$ patients, with and without mutation, presented visual acuity of 20/20 with best optical correction.

\section{Phenotypic characteristics of NDM patients}

The Cys433Arg mutation was identified in 8 of 40 subjects with no disease manifestation of both families. Among these 8 patients the median age was $14.5 \mathrm{yr}$, ranging from 3 to $43 \mathrm{yr}$ and four were female (Table 5).

The mean IOP of the NDM patients with Cys433Arg mutation was $12.5 \mathrm{mmHg}$ in the right eye and $14 \mathrm{mmHg}$ in the left eye. The IOP ranged from 10 to $19 \mathrm{mmHg}$ in the right eye and

\begin{tabular}{|c|c|c|c|c|c|c|c|c|c|c|c|c|}
\hline \multirow{3}{*}{$\begin{array}{l}\text { Patients } \\
\text { with POAG }\end{array}$} & \multirow{3}{*}{$\begin{array}{l}\text { Mutation } \\
\text { Cys433Arg }\end{array}$} & \multirow[t]{3}{*}{ Age } & \multirow[t]{3}{*}{ Gender } & \multicolumn{2}{|c|}{ Visual acuity } & \multicolumn{2}{|c|}{ Max IOP } & \multicolumn{4}{|c|}{ C/D } & \multirow[t]{3}{*}{ Surgery } \\
\hline & & & & \multirow[t]{2}{*}{ RE } & \multirow[t]{2}{*}{ LE } & \multirow[t]{2}{*}{ RE } & \multirow[t]{2}{*}{ LE } & \multicolumn{2}{|c|}{ RE } & \multicolumn{2}{|c|}{ LE } & \\
\hline & & & & & & & & V & $\mathbf{H}$ & V & $\mathbf{H}$ & \\
\hline LFN III-2 & Present & 17 & $\mathrm{~F}$ & $20 / 20$ & NLP & 32 & 58 & 0.6 & 0.4 & 1.0 & 1.0 & $\mathrm{~T}$ \\
\hline LFN I-2 & Present & 58 & $\mathrm{~F}$ & NLP & NLP & 40 & 45 & 1.0 & 1.0 & 1.0 & 1.0 & $\mathrm{~T}$ \\
\hline LFN II-10 & Present & 40 & $\mathrm{~F}$ & $20 / 20$ & $20 / 20$ & 30 & 28 & 0.4 & 0.4 & 0.6 & 0.6 & \\
\hline MAF II-10 & Present & 49 & M & NLP & FC & 40 & 35 & 1.0 & 0.9 & 1.0 & 0.9 & $T+1$ \\
\hline MAF II-2 & Present & 47 & M & MM & $20 / 40$ & 35 & 35 & 1.0 & 0.9 & 1.0 & 0.9 & $\mathrm{~T}$ \\
\hline MAF III-7 & Present & 32 & M & $20 / 20$ & $20 / 20$ & 40 & 38 & 0.8 & 0.7 & 0.8 & 0.7 & $\mathrm{~T}$ \\
\hline MAF III-1 & Present & 43 & $\mathrm{~F}$ & $20 / 20$ & $20 / 20$ & 36 & 30 & 0.7 & 0.7 & 0.7 & 0.7 & \\
\hline MAF II-12 & Present & 55 & $\mathrm{~F}$ & $\mathrm{FC}$ & $20 / 40$ & 38 & 32 & 1.0 & 0.9 & 1.0 & 0.9 & $T+1$ \\
\hline
\end{tabular}

\begin{tabular}{|c|c|c|c|c|c|c|c|c|c|c|c|}
\hline \multirow{3}{*}{$\begin{array}{l}\text { Patients } \\
\text { with } \mathrm{OH}\end{array}$} & \multirow{3}{*}{$\begin{array}{l}\text { Mutation } \\
\text { Cys433Arg }\end{array}$} & \multirow[t]{3}{*}{ Age } & \multirow[t]{3}{*}{ Gender } & \multicolumn{2}{|c|}{ Visual acuity } & \multicolumn{2}{|c|}{ Max. IOP } & \multicolumn{4}{|c|}{ C/D } \\
\hline & & & & \multirow[t]{2}{*}{ RE } & \multirow[t]{2}{*}{ LE } & \multirow[t]{2}{*}{ RE } & \multirow[t]{2}{*}{ LE } & \multicolumn{2}{|c|}{ RE } & \multicolumn{2}{|c|}{ LE } \\
\hline & & & & & & & & V & $\mathrm{H}$ & V & $\mathrm{H}$ \\
\hline LFN IV-1 & Present & 9 & $M$ & $20 / 20$ & $20 / 20$ & 24 & 22 & 0.6 & 0.5 & 0.5 & 0.5 \\
\hline LFN II-2 & Present & 48 & $M$ & $20 / 20$ & $20 / 20$ & 22 & 24 & 0.2 & 0.2 & 0.2 & 0.2 \\
\hline LFN III-13 & Absent & 21 & $\mathrm{~F}$ & $20 / 20$ & $20 / 20$ & 22 & 21 & 0.2 & 0.2 & 0.2 & 0.2 \\
\hline LFN II-8 & Present & 45 & $\mathrm{~F}$ & $20 / 20$ & $20 / 20$ & 21 & 23 & 0.4 & 0.4 & 0.4 & 0.4 \\
\hline LFN III-16 & Present & 20 & $M$ & $20 / 20$ & $20 / 20$ & 22 & 19 & 0.6 & 0.6 & 0.6 & 0.6 \\
\hline MAF III-8 & Present & 39 & M & $20 / 20$ & $20 / 20$ & 25 & 21 & 0.3 & 0.2 & 0.2 & 0.2 \\
\hline MAF III-17 & Absent & 40 & $\mathrm{M}$ & $20 / 20$ & $20 / 20$ & 30 & 30 & 0.5 & 0.5 & 0.6 & 0.6 \\
\hline
\end{tabular}


294 Correlation between genotype and phenotype in primary open angle glaucoma of Brazilian families with mutations in exon 3 of the TIGR/MYOC gene

\begin{tabular}{|c|c|c|c|c|c|c|c|c|c|c|c|}
\hline \multirow{3}{*}{$\begin{array}{l}\text { Patients } \\
\text { with NDM }\end{array}$} & \multirow{3}{*}{$\begin{array}{l}\text { Mutation } \\
\text { Cys433Arg }\end{array}$} & \multirow[t]{3}{*}{ Age } & \multirow[t]{3}{*}{ Gender } & \multicolumn{2}{|c|}{ Visual acuity } & \multicolumn{2}{|c|}{ Max IOP } & \multicolumn{4}{|c|}{$C / D$} \\
\hline & & & & \multirow[t]{2}{*}{ RE } & \multirow[t]{2}{*}{ LE } & \multirow[t]{2}{*}{ RE } & \multirow[t]{2}{*}{ LE } & \multicolumn{2}{|c|}{ RE } & \multicolumn{2}{|c|}{ LE } \\
\hline & & & & & & & & V & H & V & $\bar{H}$ \\
\hline LFN II-3 & Absent & 53 & $\mathrm{~F}$ & $20 / 20$ & $20 / 20$ & 14 & 14 & 0.4 & 0.3 & 0.4 & 0.3 \\
\hline LFN IV-2 & Absent & 6 & M & $20 / 20$ & $20 / 20$ & 10 & 10 & 0.2 & 0.2 & 0.2 & 0.2 \\
\hline LFN IV-3 & Present & 4 & $\mathrm{~F}$ & $20 / 20$ & $20 / 20$ & 11 & 10 & 0.2 & 0.2 & 0.2 & 0.2 \\
\hline LFN III-4 & Absent & 4 & M & $20 / 20$ & $20 / 20$ & 12 & 12 & 0.3 & 0.2 & 0.3 & 0.2 \\
\hline LFN I-1 & Absent & 79 & M & $20 / 100$ & $20 / 40$ & 17 & 17 & 0.1 & 0.1 & 0.1 & 0.1 \\
\hline LFN III-17 & Absent & 11 & M & $20 / 20$ & $20 / 20$ & 18 & 18 & 0.3 & 0.3 & 0.6 & 0.6 \\
\hline LFN III-9 & Absent & 31 & $M$ & $20 / 20$ & $20 / 20$ & 16 & 16 & 0.4 & 0.4 & 0.4 & 0.4 \\
\hline LFN II-9 & Absent & 46 & M & $20 / 20$ & $20 / 20$ & 17 & 15 & 0.2 & 0.2 & 0.2 & 0.2 \\
\hline LFN III-14 & Absent & 18 & M & $20 / 20$ & $20 / 20$ & 16 & 18 & 0.4 & 0.4 & 0.4 & 0.3 \\
\hline LFN III-12 & Present & 22 & M & $20 / 20$ & $20 / 20$ & 11 & 11 & 0.3 & 0.3 & 0.4 & 0.4 \\
\hline LFN III-6 & Absent & 8 & M & $20 / 20$ & $20 / 20$ & 14 & 14 & 0.3 & 0.3 & 0.3 & 0.3 \\
\hline LFN II-6 & Absent & 49 & $\mathrm{~F}$ & $20 / 20$ & $20 / 20$ & 13 & 14 & 0.2 & 0.2 & 0.2 & 0.2 \\
\hline LFN III-5 & Absent & 13 & M & $20 / 20$ & $20 / 20$ & 13 & 14 & 0.3 & 0.3 & 0.3 & 0.3 \\
\hline LFN II-12 & Absent & 48 & M & $20 / 20$ & $20 / 20$ & 16 & 18 & 0.2 & 0.2 & 0.2 & 0.2 \\
\hline LFN II-5 & Absent & 39 & M & $20 / 20$ & $20 / 20$ & 15 & 15 & 0.2 & 0.2 & 0.2 & 0.2 \\
\hline LFN III-10 & Absent & 19 & $F$ & $20 / 20$ & $20 / 20$ & 15 & 15 & 0.3 & 0.3 & 0.3 & 0.3 \\
\hline LFN III-11 & Absent & 11 & M & $20 / 20$ & $20 / 20$ & 10 & 13 & 0.7 & 0.6 & 0.6 & 0.5 \\
\hline LFN IV-5 & Present & 3 & M & $20 / 25$ & $20 / 25$ & 10 & 10 & 0.3 & 0.3 & 0.3 & 0.3 \\
\hline LFN III-15 & Absent & 19 & $\mathrm{~F}$ & $20 / 20$ & $20 / 20$ & 12 & 11 & 0.3 & 0.2 & 0.3 & 0.2 \\
\hline MAF III-19 & Absent & 35 & $\mathrm{~F}$ & $20 / 20$ & $20 / 20$ & 12 & 12 & 0.3 & 0.3 & 0.2 & 0.2 \\
\hline MAF III-20 & Absent & 26 & M & $20 / 20$ & $20 / 20$ & 20 & 18 & 0.1 & 0.1 & 0.1 & 0.1 \\
\hline MAF III-16 & Absent & 45 & $\mathrm{~F}$ & $20 / 20$ & $20 / 20$ & 12 & 12 & 0.3 & 0.3 & 0.3 & 0.3 \\
\hline MAF IV-15 & Absent & 14 & M & $20 / 20$ & $20 / 20$ & 10 & 12 & 0.1 & 0.1 & 0.1 & 0.1 \\
\hline MAF II-9 & Absent & 68 & $\mathrm{~F}$ & $20 / 60$ & $20 / 30$ & 12 & 12 & 0.3 & 0.3 & 0.3 & 0.3 \\
\hline MAF IV-19 & Absent & 13 & M & $20 / 20$ & $20 / 20$ & 10 & 10 & 0.1 & 0.1 & 0.1 & 0.1 \\
\hline MAF II-11 & Absent & 59 & M & $20 / 20$ & $20 / 20$ & 12 & 13 & 0.3 & 0.3 & 0.3 & 0.3 \\
\hline MAF III-24 & Absent & 44 & M & $20 / 20$ & $20 / 20$ & 14 & 15 & 0.3 & 0.3 & 0.3 & 0.3 \\
\hline MAF III-26 & Absent & 35 & M & $20 / 20$ & $20 / 20$ & 14 & 14 & 0.2 & 0.2 & 0.2 & 0.2 \\
\hline MAF IV-16 & Absent & 16 & $\mathrm{~F}$ & $20 / 20$ & $20 / 20$ & 12 & 12 & 0.1 & 0.1 & 0.1 & 0.1 \\
\hline MAF IV-22 & Absent & 11 & M & $20 / 20$ & $20 / 20$ & 10 & 11 & 0.2 & 0.2 & 0.2 & 0.2 \\
\hline MAF IV-23 & Absent & 18 & $F$ & $20 / 20$ & $20 / 20$ & 15 & 15 & 0.6 & 0.5 & 0.5 & 0.5 \\
\hline MAF III-27 & Present & 43 & $\mathrm{~F}$ & $20 / 20$ & $20 / 20$ & 17 & 18 & 0.2 & 0.2 & 0.3 & 0.2 \\
\hline MAF III-22 & Present & 28 & $\mathrm{~F}$ & $20 / 30$ & $20 / 80$ & 19 & 17 & 0.3 & 0.3 & 0.4 & 0.4 \\
\hline MAF IV-20 & Absent & 12 & M & $20 / 20$ & $20 / 20$ & 18 & 19 & 0.4 & 0.4 & 0.3 & 0.3 \\
\hline MAF IV-18 & Absent & 15 & M & $20 / 20$ & $20 / 20$ & 10 & 10 & 0.2 & 0.2 & 0.2 & 0.2 \\
\hline MAF III-23 & Absent & 35 & $\mathrm{~F}$ & $20 / 20$ & $20 / 20$ & 10 & 10 & 0.2 & 0.2 & 0.2 & 0.2 \\
\hline MAF III-25 & Present & 39 & $\mathrm{~F}$ & $20 / 20$ & $20 / 20$ & 11 & 10 & 0.2 & 0.2 & 0.2 & 0.2 \\
\hline MAF III-28 & Absent & 41 & M & $20 / 20$ & $20 / 20$ & 18 & 16 & 0.5 & 0.5 & 0.4 & 0.4 \\
\hline MAF IV-24 & Absent & 12 & M & $20 / 20$ & $20 / 20$ & 11 & 11 & 0.2 & 0.2 & 0.2 & 0.2 \\
\hline MAF IV-21 & Present & 7 & M & $20 / 20$ & $20 / 20$ & 14 & 17 & 0.1 & 0.1 & 0.1 & 0.1 \\
\hline MAF IV-25 & Present & 6 & M & $20 / 20$ & $20 / 20$ & 14 & 17 & 0.1 & 0.1 & 0.1 & 0.1 \\
\hline
\end{tabular}

from 10 to $18 \mathrm{mmHg}$ in the left eye. The median cup/disc ratio in the right eye of NDM patients was 0.2 and in the left eye it was 0.25 . The cup/disc ratio ranged from 0.1 to 0.4 in both eyes.

Thirty-two NDM subjects had no mutation in exon 3 of the TIGR/MYOC gene, $72 \%$ (23/32) were male and the median age of this group was $26 \mathrm{yr}$, ranging 4 to $79 \mathrm{yr}$.

The IOP median of NDM patients without mutation was 14 $\mathrm{mmHg}$ in the left eye. The median vertical cup/disc ratio was 0.3 in the right and left eye, ranging from 0.1 to 0.6 in both eyes.
The patients LFN I-1 and MAF III-22 presented deficient visual acuity due to the presence of bilateral senile cataract and refractive amblyopic respectively.

\section{Phenotypic characteristics of patients with and without mutation}

The IOP and cup/disc ratio of the subjects with or without mutation showed statistical differences (Tables $3,4,5$ ). The IOP in the group of patients with mutation was higher $(\mathrm{p}<0.001)$ than 
IOP of the patients without mutation. The NDM patients with Cys433Arg mutation had a greater cup/disc ratio when compared with those without mutation $(\mathrm{p}<0.026)$.

\section{Penetrance of mutation Cys433Arg by age groups}

The Cys433Arg mutation was identified in 5 subjects with ages between 0 and $10 \mathrm{yr}$, in 4 between 10 and $30 \mathrm{yr}$, in 4 between 30 and $40 \mathrm{yr}$ and in 8 with up to $40 \mathrm{yr}$. POAG was present in one (LFN IV-1), 2 (LFN III-2 and LFN III-16), 3 (LFN II-10, MAF III-7 and MAF III-8) and 7 patients (LFN I-2, LFN II-2, LFN II-8, MAF II-2, MAF II-10, MAF II-12, MAF III-1) with Cys433Arg mutation corresponding to $20 \%, 50 \%$, $75 \%$ and $87,5 \%$, respectively, according to the age groups (Tables 3, 4, 5).

\section{DISCUSSION}

POAG is a complex genetic disease that presents a range of ocular signs that are poorly understood in regard to their pathophysiology $y^{(12)}$.

One of the main benefits obtained by genetic study in this type of disease is the identification of subjects who are at risk of developing $i^{(12)}$. Considering that the mutation in the TIGR/ MYOC gene is responsible for the disease, the observation of the phenotype caused by different mutations may result in characterization of specific clinical situations determined by mutations ${ }^{(12-13)}$. Therefore, clinical and molecular analyses were performed in 96 Brazilian unrelated subjects.

The Cys433Arg residue is located in the region of the more preserved amino acids in the olfatomedin domain of myocilin. Thus, any alteration in this region is expected to alter the structure of the protein causing disease ${ }^{(17)}$. This residue might play an important role in the establishment of intermolecular connections of the "myocilin" protein. Amino acid substitution in this region could prevent myocilin olygomeric complexes formation. Therefore, endangering myocilin intermolecular relations may imply in increased resistance of aqueous humor drainage, through the trabecular meshwork ${ }^{(18)}$.

The non-conservative Cys433Arg mutation was first described by Vasconcellos et al ${ }^{(10)}$ in patients with juvenile and adult POAG. These authors analyzed the haplotypes of the patients with Cys433Arg mutation and observed that these patients had a common ancestor, suggesting that this mutation, described only in the Brazilian population, should have founder effect ${ }^{(19)}$.

Specific mutations are described in different population groups ${ }^{(8,9)}$. The Cys433Arg mutation was the most prevalent amino acid substitution in a series of 28 Brazilian patients with J-POAG and in our series of 96 patients with POAG. Therefore, Cys433Arg probably is the most frequent POAG causing mutation in the Brazilian population ${ }^{(10,19)}$.

In all but Eastern population, the most frequent identified mutation in the TIGR/MYOC gene is Gln368STOP. This mutation has been associated with juvenile-onset and adult POAG.
The average age at diagnosis of POAG in subjects with this mutation varied according to the different authors: Shimizu et al. ${ }^{(20)}$ found an average age of $37 \mathrm{yr}$, ranging from 27 to $49 \mathrm{yr}$, whereas Allingham et al ${ }^{(21)}$ reported an average age of $62 \mathrm{yr}$, ranging from 41 to $75 \mathrm{yr}$ and Alward et $\mathrm{al}^{(14)}$ reported an average age of $59 \mathrm{yr}$, ranging from 36 to $77 \mathrm{yr}$. The mutation Gln368STOP has variable relevance and can be found in normal patients, ocular hypertensive patients and those with POAG. Nevertheless, both population and family studies suggest that there is a greater risk of development of the disease in subjects with Gln368STOP mutation.

The Cys433Arg mutation seems to present phenotypic heterogeneity similar to Gln368STOP. It was found in patients with juvenile-onset and adult POAG. In both families evaluated in this study the median age at diagnosis of POAG was $45 \mathrm{yr}$, ranging from 17 to $63 \mathrm{yr}$. The average age at diagnosis found by Vasconcellos ${ }^{(10)}$, evaluating patients with J-POAG, was $27.6 \mathrm{yr}$, ranging from 20 to 35 years.

The study of the families LFN and MAF showed that Cys433Arg mutation co-segregates with the disease. All subjects with diagnosis of POAG had this mutation. These data suggest that the Cys433Arg mutation, in exon 3 of the TIGR/ MYOC gene is associated with the development of POAG.

The patients with mutation presented greater median IOP without medication, and also greater median of vertical cup/ disc ratio when compared to patients without mutation.

In practice, the analysis of these results allowed the identification of patients likely at high risk of disease development

Two OH patients (LFN III-13 and MAF III-17) did not have mutation in exon 3 of the TIGR/MYOC gene. Patient LFN III13, 21 years old, may be part of a group of $\mathrm{OH}$ patients that shall never develop glaucoma. Patient MAF III-17, 40 years old, presented maximal IOP without medication of $30 \mathrm{mmHg}$ and had his ocular hypertensive pressure treated by professionals from another institution. As patient MAF III-17 and LFN III-13 had no mutation in exon 3 of the TIGR/MYOC gene we may suggest that another region of this gene or another gene can determine this phenotype ${ }^{(23-27)}$. Environmental effects could also be implied, making this patient a phenocopy. What turns the interpretation of these data difficult is the fact that the patient comes from a family with a mutation of high penetrance that possibly causes this disease. Nevertheless, the evaluation of central corneal thickness could explain the ocular hypertension ${ }^{(28)}$.

Although some studies show relationship between the TIGR/MYOC gene and POAG, the role of myocilin in the glaucoma pathophysiology is not completely understood ${ }^{(20,29)}$. In this context, other genes and proteins maybe interact in the genesis of POAG. The presence of sequence variants in the consensus region of the promoter region could interfere altering the MYOC/TIGR expression ${ }^{(30)}$.

The Arg96Stop identified in the Chinese population did not cause the disease in a 77-year-old proband with a homozygous mutation. A mutation that creates a stop codon in the beginning of the gene, probably results in a truncated protein. 
Unless another translation initiation codon (methionine) occurs downstream the mutated codon, this gene or this region of the gene plays no key role in the genesis of this disease. This observation could weaken the role of myocilin in glaucoma pathophysiology.

In respect to Cys433Arg mutation, only the evaluation of other families and, mainly, the follow-up of patients with this mutation without manifestation of the disease and ocular hypertension will provide reliable conclusions about penetrance.

The screening of mutations for POAG is not a factual method of diagnosis and there are many and different involved loci, with countless identified mutations. The pathophysiology of POAG remains little understood and functional studies of the Cys433Arg mutation could improve the knowledge about the structure and function of myocilin. Greater accuracy and availability of the techniques of genetic screening are necessary before these tools can be incorporated into clinical practice.

\section{RESUMO}

Objetivo: Identificar nos representantes de famílias com glaucoma primário de ângulo aberto (GPAA) mutações no exon 3 do gene TIGR/MYOC e avaliar a expressão fenotípica associada às mutações encontradas em seus respectivos núcleos familiares. Métodos: Setenta e oito pacientes $(81,2 \%)$, com pelo menos um representante na família com GPAA, e dezoito pacientes $(18,7 \%)$ com glaucoma esporádico tiveram o exon 3 , do gene TIGR/MYOC, submetido a seqüenciamento automático para identificação de mutações. Os pacientes, com mutação não silenciosa identificadas nesta triagem inicial, tiveram os heredogramas de suas famílias construídos. Todos os seus familiares disponíveis foram submetidos a exame oftalmológico e seqüenciamento automático do exon 3, do gene TIGR/MYOC. Resultados: Foram identificados quatro tipos de variações na seqüência do exon 3 do TIGR/MYOC (Cys433Arg, Pro370Pro, Lys398Arg e Tyr347Tyr) nos 96 pacientes inicialmente estudados. A mutação Lys398Arg previamente descrita como polimorfismo não segregou com a doença na família estudada. A mutação Cys433Arg foi a mais prevalente afetando 3,1\% da amostra inicial (3/96). Em duas diferentes famílias (56 integrantes disponíveis para exame), 8/56 carregavam a mutação Cys433Arg e tinham GPAA, 5/56 com mutação eram hipertensos oculares e 8/56 com mutação não apresentavam manifestações da doença. Pacientes com GPAA apresentaram mediana de idade de diagnóstico de 43,25 anos, variando entre 17-58, e média de pressão intra-ocular (PIO) de $36,3 \pm 3,8 \mathrm{mmHg}$ para olho direito e $37,6 \pm 9,75 \mathrm{mmHg}$ para olho esquerdo. $\mathrm{O}$ grupo com a mutação Cys433Arg apresentou PIO significantemente mais elevada $(\mathrm{p}<0,0007)$ e relação escavação/disco vertical mais comprometida $(\mathrm{p}<0,023)$ que o grupo de pacientes sem mutação. Conclusão: A mutação no exon 3 do gene TIGR/MYOC associa-se com famílias brasileiras portadoras de GPAA de início precoce. O fenótipo desta mutação é caracterizado por variável idade de diagnóstico, causando GPAA-juvenil e GPAA do adulto, PIO bastante elevada, de difícil controle, freqüentemente levando a grave comprometimento visual.

Descritores: Glaucoma de ângulo aberto; Genes; Fenótipo; Genótipo; Mutação; Triagem genética; Brasil

\section{REFERENCES}

1. Quigley HA. Number of people with glaucoma worldwide. Br J Ophthalmol 1996;80(5):389-93. Review.

2. Thylefors B, Negrel AD. The global impact of glaucoma. Bull World Health Organ. 1994;72(3):323-6.

3. Ghanem CC. Levantamento de casos de glaucoma em Joinville - Santa Catarina, 1984. Arq Bras Oftalmol. 1989;52(2):40-3.

4. Povoa CA, Nicolela MT, Valle ALSL, Gomes LES, Neustein I. Prevalência de glaucoma identificada em campanha de detecção em São Paulo. Arq Bras Oftalmol. 2001;64(4):303-7.

5. Sheffield VC, Stone EM, Alward WL, Drack AV, Johnson AT, Streb LM, Nichols BE. Genetic linkage of familial open angle glaucoma to chromosome 1q21-q31. Nat Genet. 1993;4(1):47-50.

6. Stone EM, Fingert JH, Alward WL, Nguyen TD, Polansky JR, Sunden SL, et al. Identification of a gene that causes primary open angle glaucoma. Science. 1997;275(5300):668-70.

7. Rozsa FW, Shimizu S, Lichter PR, Johnson AT, Othman MI, Scott K, et al. GLC1A mutations point to regions of potential functional importance on the TIGR/MYOC protein. Mol Vis. 1998;4:20.

8. Fingert JH, Heon E, Liebmann JM, Yamamoto T, Craig JE, Rait J, et al Analysis of myocilin mutations in 1703 glaucoma patients from five different populations. Hum Mol Genet. 1999;8(5):899-905.

9. Lam DS, Leung YF, Chua JK, Baum L, Fan DS, Choy KW, Pang CP. Truncations in the TIGR gene in individuals with and without primary openangle glaucoma. Invest Ophthalmol Vis Sci. 2000;41(6):1386-91.

10. Vasconcellos JP, Melo MB, Costa VP, Tsukumo DM, Basseres DS, Bordin $\mathrm{S}$, et al. Novel mutation in the MYOC gene in primary open glaucoma patients. J Med Genet. 2000;37(4):301-3.

11. Anderson, DR. Automated static perimetry. St Louis: Mosby Year Book; c1992

12. Quigley HA. The search for glaucoma genes-implications for pathogenesis and disease detection. N Engl J Med. 1998;338(15):1063-4.

13. Mathew C. Science, medicine, and the future: Postgenomic technologies: hunting the genes for common disorders. BMJ. 2001;322(7293):1031-4. Review.

14. Alward WL, Fingert JH, Coote MA, Johnson AT, Lemer SF, Junqua D, et al. Clinical features associated with mutations in the chromosome 1 openangle glaucoma gene (GLC1A). N Engl J Med. 1998;338(15):1022-7.

15. Richards JE, Ritch R, Lichter PR, Rozsa FW, Stringham HM, Caronia RM, et al. Novel trabecular meshwork inducible glucocorticoid response mutation in an eight-generation juvenile-onset primary open-angle glaucoma pedigree. Ophthalmology. 1998;105(9):1698-707.

16. Craig JE, Baird PN, Healey DL, McNaught AI, McCartney PJ, Rait JL, et al Evidence for genetic heterogeneity within eight glaucoma families, with the GLC1A Gln368STOP mutation being an important phenotypic modifier. Ophthalmology. 2001;108(9):1607-20.

17. Nguyen TD, Chen P, Huang WD, Chen H, Johnson D, Polansky JR. Gene structure and properties of TIGR, an olfactomedin-related glycoprotein cloned from glucocorticoid-induced trabecular meshwork cells. J Biol Chem. 1998; 273(11):6341-50.

18. Fingert JH, Stone EM, Sheffield VC, Alward WL. Myocilin glaucoma. Surv Ophthalmol. 2002;47(6):547-61. Review.

19. de Vasconcellos JP, de Melo MB, Schimiti R, Costa FF, Costa VP. Penetrance and phenotype of the Cys433Arg myocilin mutation in a family pedigree with primary open-angle glaucoma. J Glaucoma. 2003;12(2):104-7.

20. Shimizu S, Lichter PR, Johnson AT, Zhou Z, Higashi M, Gottfredsdottir M, et al. Age-dependent prevalence of mutations at the GLC1A locus in primary open-angle glaucoma. Am J Ophthalmol. 2000;130(2):165-77.

21. Allingham RR, Wiggs JL, De La Paz MA, Vollrath D, Tallett DA, Broomer 
B, et al. Gln368STOP myocilin mutation in families with late-onset primary open-angle glaucoma. Invest Ophthalmol Vis Sci. 1998;39(12):2288-95.

22. Trifan OC, Traboulsi EI, Stoilova D, Alozie I, Nguyen R, Raja S, Sarfarazi M. A third locus (GLC1D) for adult-onset primary open-angle glaucoma maps to the 8q23 region. Am J Ophthalmol. 1998;126(1):17-28.

23. Wirtz MK, Samples JR, Rust K, Lie J, Nordling L, Schilling K, et al. GLC1F, a new primary open-angle glaucoma locus, maps to 7q35-q36. Arch Ophthalmol. 1999;117(2):237-41.

24. Stoilova D, Child A, Trifan OC, Crick RP, Coakes RL, Sarfarazi M. Localization of a locus (GLC1B) for adult-onset primary open angle glaucoma to the 2cen-q13 region. Genomics. 1996;36(1):142-50.

25. Wirtz MK, Samples JR, Kramer PL, Rust K, Topinka JR, Yount J, et al Mapping a gene for adult-onset primary open-angle glaucoma to chromosome 3q. Am J Hum Genet. 1997;60(2):296-304

26. Sarfarazi M, Child A, Stoilova D, Brice G, Desai T, Trifan OC, et al.
Localization of the fourth locus (GLC1E) for adult-onset primary open-angle glaucoma to the 10p15-p14 region. Am J Hum Genet. 1998;62(3):641-52.

27. Rezaie T, Child A, Hitchings R, Brice G, Miller L, Coca-Prados M, et al Adult-onset primary open-angle glaucoma caused by mutations in optineurin. Science. 2002;295(5557):1077-9.

28. Copt RP, Thomas R, Mermoud A. Corneal thickness in ocular hypertension, primary open-angle glaucoma, and normal tension glaucoma. Arch Ophthalmol. 1999;117(1):14-6.

29. Gould DB, Miceli-Libby L, Savinova OV, Torrado M, Tomarev SI, Smith RS, John SW. Genetically increasing Myoc expression supports a necessary pathologic role of abnormal proteins in glaucoma. Mol Cell Biol. 2004;24(20):9019-25.

30. Saura M, Cabana M, Ayuso C, Valverde D. Mutations including the promoter region of myocilin/TIGR gene. Eur J Human Genet. 2005;13(3):384-7.

31. Cohen CS, Allingham RR. The dawn of genetic testing for glaucoma. Curr Opin Ophthalmol. 2004;15(2):75-9. Review.

\title{
XV Congresso Norte-Nordeste de Oftalmologia
}

\section{6 с 8 de Setembre de 2006}

\section{Multicenter SEBRAE São Luís - MA}

\section{INFORMAÇÕES: Taguatur Eventos}

\author{
Av. dos Holandeses, s/no - Térreo do Hotel Belagio \\ CEP 65075-650 - São Luís - MA \\ Telefax: (98) 3213-6350 / (98) 8126-5958 com Maria Luiza \\ E-mail: marialuiza@taguatur.com.br \\ Home-page: oftalmo2006nne.com.br
}

